\title{
How Store Image Affect Satisfaction and Loyalty:
}

\author{
A Structural Model for Traditional Market
}

\author{
Moh Farid Najib* \\ Business Administration Department \\ Bandung State Polytechnic \\ Bandung, Indonesia \\ *mohfaridnajib@polban.ac.id
}

\begin{abstract}
The quality of traditional market services is less competitive when compared to modern markets. The condition occurs because traditional retail is perceived as a slum, chaotic, muddy, dirty, and lack of facilities such as limited parking area, smelly and dirty trash cans, hallways, narrow and so on Store image is an important factor for customers in creating customer satisfaction and loyalty. This paper aims to measure the effect of store image on customer satisfaction and loyalty in the context of traditional markets. This research has been conducted on 400 customers in 16 traditional markets in West Java, Indonesia. A procedure of structural equation modeling has been applied to evaluate the proposed research model. The methodology used consists of two stages. The first step was to see the construct validity through Convergent Validity (CV), Average Variance Extracted (AVE), Construct Reliability (CR), and Discriminant Validity (DC). Secondly, structural equation modeling. The results reveal that store image has positively influenced customer satisfaction; however, they show a non-significant effect on customer loyalty. Furthermore, satisfaction also positively influences loyalty.
\end{abstract}

Keywords—store-image, customer satisfaction, customer loyalty

\section{INTRODUCTION}

Competition in the retail business is very competitive, where revenue and profit are largely determined by the "share of wallet" of customers [1,2]. Meanwhile, the key factors for the success of retail performance are determined by how to make loyalty, retention, and the intention to make repeat purchases $[3,4]$. In the context of traditional markets, it is necessary to apply appropriate marketing strategies on how to identify the concept of loyalty models. Meanwhile, the quality of traditional market services is less competitive when compared to modern markets [5], the condition occurs because traditional retail is perceived as a slum, chaotic, muddy, dirty, and lack of facilities such as limited parking area, smelly and dirty trash cans, hallways, narrow and so on [6].

Several studies in the retail sector state that one of the main drivers of loyalty as well as repurchase intention directly is store image $[3,7]$, and indirectly through customer satisfaction [8]. Store image consists of various procedures that must be followed by customers in the physical environment of the store, the situation when in direct contact with employees/sellers, and retailer offerings [9]. Store image has been described as a function of the main attributes that are evaluated and considered from one store to another [8]. Store image and satisfaction together influence loyalty [10,11]. High service quality will result in high customer satisfaction and increase customer loyalty [12]. Customer satisfaction is a significant predictor of customer loyalty [13].

In general, satisfaction is believed to have a positive influence on loyalty, although this influence is highly dependent on the different factors, such as the types and industries being analyzed [14]. Over the last few decades, several authors have dedicated their study to the topic of loyalty $[15,16]$. Loyalty is seen as a customer's willingness to make personal sacrifices to strengthen the relationship between them [15]. Customer loyalty is a manifestation of various ways including customer commitment to make repeat purchases or as a preference for the product or service chosen $[17,18]$ So that customer loyalty is a behavior or attitude of the customer [19]. The behavioral approach can be said to be customer loyalty shown by making repeat purchases [20,21].

Customer involvement in each retail is strongly influenced by information about merchandise in the store [22], and these factors as a whole shape the store image. The retail company image plays an important role in creating customer satisfaction [23]. Therefore, the store image becomes attached to the minds of customers when comparing the level of satisfaction they get related to the shopping experience and the suitability of their expectations between the current store and other stores [24]. When customers visit a retail store, their expectations from the store before shopping are not only based on their recent experience but also word of mouth marketing through other customers [25]. Likewise, shop personnel who engage customers will be a strong factor that has a significant influence on store image [26].

The store image plays an important role in the level of customer satisfaction [23]. Store image has a positive effect on customer loyalty through customer satisfaction [27]. Customer satisfaction is highly dependent on store image, and store image also has a very significant effect on customer loyalty, while the store image affects customer loyalty through 
customer satisfaction $[8,14,28]$. Meanwhile, a high level of customer satisfaction will affect a high level of customer loyalty as well [29]. However, consumer perceptions of store image are related to customer satisfaction but have no direct effect on customer loyalty [30].

The integration of the overall store image with satisfaction has been analyzed empirically as a driver of customer loyalty in more general structural models [25]. Therefore, this paper aims to evaluate the role of store image and satisfaction as a direct impact on customer loyalty in a traditional market context. The novelty of the article is to put a structural model.

\section{Methodology}

For data collection purposes, the survey was distributed to 400 respondents from 16 traditional markets around West Java, Indonesia. Respondents were asked to respond to a questionnaire that had 22 items. All these variable constructs are measured on a five-point Likert scale, which ranges from strongly disagree to strongly agree. Following this process, the instrument (in Indonesian) was tested on 20 traditional market customers to evaluate the suitability of the questionnaire instructions and questions. Respondent responses were filtered and processed using SPSS-23 after collection, and data were filtered for univariate and multivariate outliers, to obtain accurate results. After the initial screening of the data with the help of SPSS-23, the data were then statistically analyzed on a structural equation model (SEM) using AMOS-23 software.

The research model developed to answer the research objectives is as shown in Figure 1, and the research model developed to answer the research objectives is as shown in Figure 1, and the hypothesis is as follows.

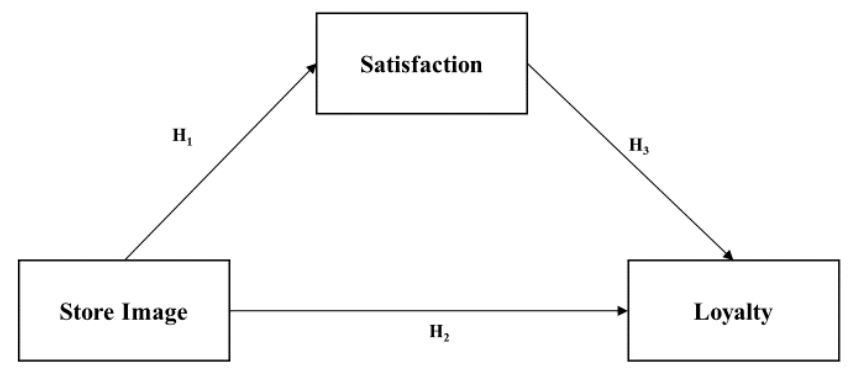

Fig. 1. Research model.

H1: Store image of the traditional market impacts on customer satisfaction significantly

$\mathrm{H} 2$ : Store image of the traditional market impacts on customer loyalty significantly

H3: Customer satisfaction of the traditional market significantly impacts customer loyalty

\section{RESULTS}

\section{A. Reliability Analysis and Measurement Model}

Research instruments need to be done so that the questionnaire can describe the level of stability, consistency, and homogeneity, besides that the questionnaire must be clear, easy to understand, comprehensive, consistent, firm, and noncausal, and should not lead to unclear answers. Reliability test using SPSS 23 (see Table 1). The results of the reliability analysis show that both the dimensions and the sub-dimensions show that the Cronbach's Alpha coefficient is more than 0.7 which means it is very reliable [31,32]. Besides, confirmatory factor analysis was used to test the structure of the construct factor, and to estimate model parameters. This analysis also examines the multidimensionality of theoretical constructs. Besides, loading factor is an indicator of reliability, as well as testing for convergent validity by calculating the level of AVE (average variance extracted), CR (Construct reliability), and Cronbach's $\alpha$ coefficients as well as discriminant validity as shown in Table 1, all of which are reflective evaluations of the measurement model [33].

TABLE I. RELIABILITY AND MEASUREMENT MODEL

\begin{tabular}{|c|c|c|c|c|c|}
\hline $\begin{array}{l}\text { Dimensions/ } \\
\text { Sub- } \\
\text { dimensions }\end{array}$ & $\begin{array}{l}\text { Loading } \\
\text { Factor }\end{array}$ & \begin{tabular}{|c|} 
Reliability \\
Stasitics \\
(Cronbach's \\
Alpha) \\
\end{tabular} & $\begin{array}{l}\text { Average } \\
\text { Variance } \\
\text { Extracted }\end{array}$ & $\begin{array}{l}\text { ConstructI } \\
\text { Reliability }\end{array}$ & $\begin{array}{l}\text { Pistriminant } \\
\text { Validity }\end{array}$ \\
\hline Store Image & & $\mathbf{0 , 9 3 7}$ & & & \\
\hline $\begin{array}{l}\text { Merchandise } \\
\text { MC4 } \\
\text { MC3 } \\
\text { MC2 } \\
\text { MC1 }\end{array}$ & $\begin{array}{l}0,884 \\
0,908 \\
0,837 \\
0,632\end{array}$ & 0,885 & 0,750 & 0,935 & 0,866 \\
\hline $\begin{array}{l}\text { Layout } \\
\text { LY3 } \\
\text { LY2 } \\
\text { LY1 }\end{array}$ & $\begin{array}{l}0,86 \\
0,69 \\
0,715\end{array}$ & 0,806 & 0,576 & 0,875 & 0,759 \\
\hline $\begin{array}{l}\text { Personnel } \\
\text { PL4 } \\
\text { PL3 } \\
\text { PL2 } \\
\text { PL1 }\end{array}$ & $\begin{array}{l}0,829 \\
0,845 \\
0,888 \\
0,773 \\
\end{array}$ & 0,900 & 0,697 & 0,944 & 0,835 \\
\hline $\begin{array}{l}\text { Satisfaction } \\
\text { SF6 } \\
\text { SF5 } \\
\text { SF4 } \\
\text { SF3 } \\
\text { SF2 } \\
\text { SF1 }\end{array}$ & $\begin{array}{l}0,865 \\
0,904 \\
0,844 \\
0,885 \\
0,885 \\
0,693 \\
\end{array}$ & 0,949 & 0,776 & 0,975 & 0,881 \\
\hline $\begin{array}{l}\text { Loyality } \\
\text { LOY5 } \\
\text { LOY4 } \\
\text { LOY3 } \\
\text { LOY2 } \\
\text { LOY1 }\end{array}$ & $\begin{array}{l}0,902 \\
0,947 \\
0,955 \\
0,939 \\
0,897 \\
\end{array}$ & 0,968 & 0,795 & 0,972 & $\mathbf{0 , 8 9 2}$ \\
\hline
\end{tabular}

The loading factor shows a significant level, with a score between 0.690 to 0.908 , and an AVE value with a value greater than 0.5 , so that convergent validity can be supported [34]. Besides, as the Cronbach's $\alpha$ coefficients for all constructs show very good reliability with the values greater than 0.70 
[35], and also for Construct reliability (CR) with a criterion value greater than 0.60 [36], Then the Fornell-Larcker criteria approach is used, for discriminant validity [37]. This approach will assess the square root of each construct's AVE (average variance extracted), which shows a higher value than the highest correlation value of other constructs $[33,38]$. As shown in Table 1 , the correlation between constructs is from 0.576 to 0.795 , this result ensures a measure of discriminant validity.

\section{B. Structural Equation Modeling}

The Structural Equation Model is used for testing measurement models using the AMOS-23 software. Evaluation of the relevance of predictions and hypothesis testing is carried out to determine the relationship between variables empirically. Figure 2 shows the results of the path model, where the proposed operational model shows that CMIN / DF $(2,675)$, RMSEA (0.076), GFI (0.93), AGFI (0.915), TLI (0.92), CFI (0.932), NFI (0.92), IFI (0.932), and RFI score (0.901), these results indicate that there is compatibility between the hypothesized models and the research data.

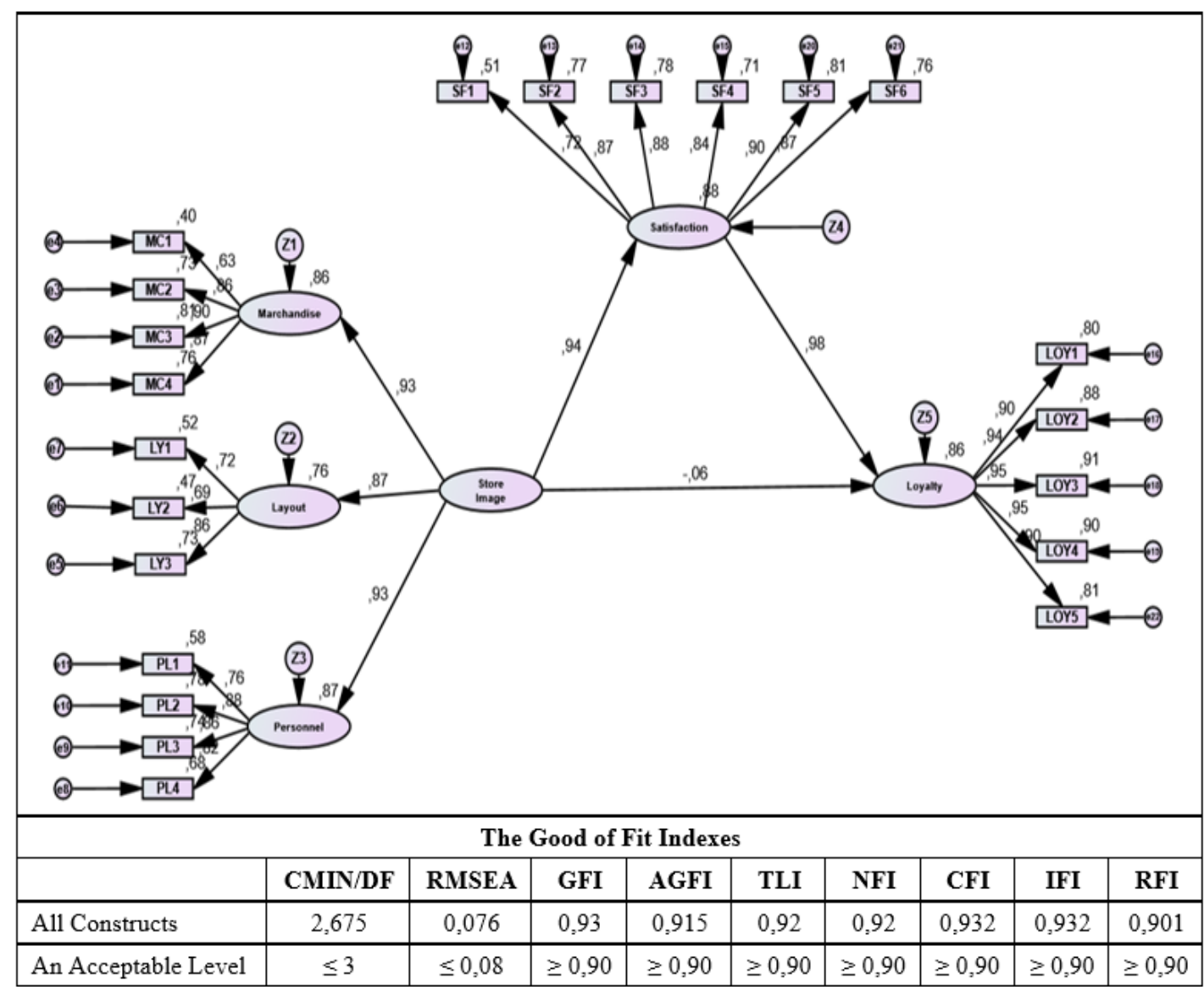

Fig. 2. Structural equation model.

\section{Discussion}

The purpose of this research is to analyze the effect of store image, customer satisfaction, and loyalty in the context of the
Indonesian traditional market. Based on the results shown in Figure 1 and Table 2, the effect of these variables is clear: store image, customer satisfaction, and customer loyalty.

TABLE II. HYPOTHESIS TESTING RESULTS

\begin{tabular}{|ll|l|l|l|l|l|}
\hline \multicolumn{2}{c|}{ Hypothesis } & $\begin{array}{c}\text { Stand. } \\
(\text { Est) }\end{array}$ & SE & CR & $\begin{array}{c}\text { P } \\
\text { Value }\end{array}$ & Result \\
\hline $\mathrm{H}_{1}$ Store Image $\rightarrow$ Customer Satisfaction & .818 & .055 & 14.957 & $* * *$ & Accepted \\
\hline $\mathrm{H}_{2}$ Store Image $\rightarrow$ Customer Loyality & -0.063 & .119 & -0.596 & .597 & Rejected \\
\hline $\begin{array}{l}\mathrm{H}_{3} \text { Custemer Satisfaction } \rightarrow \text { Customer } \\
\text { Loyality }\end{array}$ & 1.209 & .149 & 8.099 & $* * *$ & Accepted \\
\hline
\end{tabular}


To test the research hypothesis, we used hierarchical linear regression analysis. Based on standard parameter estimates, the results provide support for $\mathrm{H} 1$ (store image $\rightarrow$ customer satisfaction) and $\mathrm{H} 3$ (customer satisfaction $\rightarrow$ customer loyalty) (stand. Est $=0.818, \mathrm{SE}=0.055, \mathrm{CR}=14,957, \mathrm{P}$-Value $* * *$; stand. Est $=1.209, \mathrm{SE}=0.149, \mathrm{CR}=8.099, \mathrm{P}-$ Value $* * *$, respectively). Meanwhile, H2 (store image $\rightarrow$ customer loyalty), there is no relationship between this relationship from respondents (stand. Est $=-0.063, \mathrm{SE}=0.119, \mathrm{CR}=-0.596, \mathrm{P}$ Value $=0.597)$

H1 (Store image of the traditional market impacts on customer satisfaction significantly) displays a Critical Ratio (CR) of 14,957 for the effect of store image on customer satisfaction, the P-value (probability) is significant with *** which means that by default it is significant. This means that the regression value for customer satisfaction is projected from the store image. Customer satisfaction differs from zero at the 0.05 (two-sided) level, therefore $\mathrm{Ho}$ is rejected, and $\mathrm{Ha}$ is accepted. The results of the study concluded that store image influences customer satisfaction of traditional market customers in West Java, Indonesia. Store image directly contributes $94 \%$ to customer satisfaction. This means that traditional market customers are satisfied with the image of the traditional market. The effect of store image on customer satisfaction supports the previous opinion [23,25]. Furthermore, a good store image will make consumers more comfortable and satisfied [38], although, in reality, it shows that the image of a traditional market is perceived as a slum, chaotic, muddy, dirty, and lack of facilities such as limited parking space, smelly and dirty trash cans, aisles. narrow and so on [6]. This happens because traditional markets can provide fresh products, open from early morning, with a busy atmosphere.

H2 (Store image of the traditional market impacts on customer loyalty significantly) provides a critical value $(\mathrm{CR})$ of -0.063 on the effect of store image on customer loyalty, on a significant P-value (probability) of 0.597 which is not significant. This shows that the customer loyalty regression value is not projected by the store image so that Ho is accepted, and $\mathrm{Ha}$ is rejected. Therefore, it can be concluded that This happens because traditional markets can provide fresh products, open from early morning, with a busy atmosphere. The results showed that store image had no direct effect on loyalty. The results of this study are different from previous studies, which state that store image is one of the main drivers of loyalty or direct repurchase intention [3,7]. Store image and satisfaction together influence loyalty $[10,11]$. This condition occurs because, in traditional markets, the market layout is narrow, muddy, and smelly [6]. Besides that, the arrangement of merchandise makes it difficult for buyers, as well as the number of people who offer the same product at the traditional market which makes customers choose another store.

H3 (Customer satisfaction of the traditional market significantly impacts on customer loyalty) reveals the critical value $(\mathrm{CR})$ of 8,099 on the effect of customer satisfaction on customer loyalty, on the significance of P-value (probability) with *** showing significant by default. This means the regression weights for projected customer loyalty. Customer satisfaction differs from zero at the 0.05 level (two sides), as a result, $\mathrm{Ho}$ is rejected, and $\mathrm{Ha}$ is accepted. Thus, it can be concluded that traditional market consumer satisfaction in West Java Indonesia directly gives $98 \%$ of consumer loyalty. This means that traditional market buyers have loyalty. The results of this study prove that customer satisfaction has a direct and positive effect on customer loyalty. This finding is in line with the previous study $[5,25]$. This condition occurs because the completeness of products in traditional markets is the cause of customer loyalty, in addition to fresh products, and is open from early in the morning.

\section{CONCLUSION}

This research was conducted by using the estimation technique in the structural model to measure the level of satisfaction and loyalty of traditional market customers in an interrelated way and to see the potential driver, namely the image of the traditional market itself, without paying attention to other drivers. The results of this research can be concluded that the image of the traditional market is a factor that needs to be considered to encourage customer loyalty in the traditional market. The condition of traditional markets is perceived as a slum, chaotic, muddy, dirty, and lack of facilities such as limited parking spaces, smelly and dirty trash cans, narrow alleys, and so on have made the image of traditional markets a major problem, even though customers are satisfied.

This research provides various insights for traditional market managers as well as decision-makers. First, this study shows that the image of traditional markets is related to the market layout factors that encourage the satisfaction and loyalty of traditional market customers. Second, traditional market managers need to increase their concern for the image of traditional markets, related to cleanliness, market layout. Narrow corridors need to be structured so that traditional markets can make modern traditional markets.

\section{ACKNOWLEDGMENT}

This research is part of large research on traditional markets. This research was funded by the Bandung State Polytechnic for the 2020 Fiscal Year.

\section{REFERENCES}

[1] C. A. Bustos-Reyes and Ó. González-Benito, "Store and store format loyalty measures based on budget allocation," J. Bus. Res., vol. 61, no. 9, pp. 1015-1025, 2008

[2] M. Hernant, T. Andersson, and O. Hilmola, "Managing retail chain profitability based on local competitive conditions: preliminary analysis," Int. J. Retail Distrib. Manag., vol. 35, no. 11, pp. 912-935, 2007.

[3] Y. Pan and G. M. Zinkhan, "Determinants of retail patronage: a metaanalytical perspective," J. Retail., vol. 82, no. 3, pp. 229-243, 2006

[4] M. Martos-Partal and O. González-Benito, "The effects of store brand loyalty on store loyalty: evidence from the Spanish market," Int. Rev. Retail. Distrib. Consum. Res., vol. 19, no. 3, pp. 273-288, 2009. 
[5] [5] M.F. Najib and A. Sosianika, "Retail service quality, satisfaction, and trust: The key to shopper loyalty in the context of the Indonesian traditional market,” Int. J. Electron. Mark. Retail., vol. 10, no. 4, 2019.

[6] M.F. Najib and A. Sosianika, "Retail service quality scale in the context of Indonesian traditional market,” Int. J. Bus. Glob., vol. 21, no. 1, 2018.

[7] J.-S. Chen, R.K.H. Ching, and H.T. Tsou, "Multi-channel store image and the effects on purchase intention," Serv. Ind. J., vol. 29, no. 9, pp. 1215-1230, 2009

[8] J. Bloemer, K. De Ruyter, and P. Peeters, "Investigating drivers of bank loyalty: the complex relationship between image, service quality and satisfaction,” Int. J. bank Mark., vol. 16, no. 7, pp. 276-286., 1998.

[9] D. Morschett, B. Swoboda, and T. Foscht, "Perception of store attributes and overall attitude towards grocery retailers: The role of shopping motives," Int. Rev. Retail. Distrib. Consum. Res., vol. 15, no. 4, pp. $423-447,2005$.

[10] S. Ene and B. Özkaya, "A study on corporate image, customer satisfaction and brand loyalty in the context of retail stores," Asian Soc. Sci., vol. 10, no. 14, p. 52, 2014.

[11] K. Moorthy, L.C. T’ing, S.A. Na, C.T. Ching, L.Y. Loong, L.S. Xian, and T.W. Ling, "Corporate image no longer leads to customer satisfaction and loyalty: a Malaysian perspective," Int. J. Law Manag., vol. 60, no. 4, pp. 934-952, 2018.

[12] M. Kumar, F.T. Kee, and A.T. Manshor, "Determining the relative importance of critical factors in delivering service quality of banks," Manag. Serv. Qual. An Int. J., vol. 19, no. 2, pp. 211-228, 2009.

[13] Y.Y. Cheng, C.C., Chiu, S.I., Hu, H.Y. and Chang, "A study on Exploring the Relationship Between Customer and Loyalty in the FastFood Industry: With Relationship Inertia as a Mediator5118-5126.," African J. Bus. Manag., vol. 5, no. 13, pp. 5118-5126, 2011.

[14] A.R. Biscaia, M.J. Rosa, P.M. e Sá, and C. S. Sarrico, "Assessing customer satisfaction and loyalty in the retail sector," Int. J. Qual. Reliab. Manag., vol. 34, no. 9, pp. 1508-1529., 2017.

[15] F.F. Reichheld, "The one number you need to grow," Harv. Bus. Rev., vol. 82, no. 6, p. 133, 2004.

[16] R.L. Oliver, "A Cognitive Model of the Antecedents and Consequences of Satisfaction Decisions," J. Mark. Res., vol. 17(4), no. November, pp. 460-469, 1980.

[17] R.L. Oliver, Behavioral perspective on the consumer. New York: McGraw-Hill//Irwin, 1997

[18] F.F. Reichheld and W.E. Sasser, "Zero defeofions: Quoliiy comes to services,” Harv. Bus. Rev., vol. 68, no. 5, pp. 105-111, 1990

[19] V.A. Zeithaml, "Service quality, profitability, and the economic worth of customers: what we know and what we need to learn," J. Acad. Mark. Sci., vol. 28 , no. 1 , pp. $67-85,2000$.

[20] J. Kandampully, "Service management: The new paradigm in retailing," in Service Management: The New Paradigm in Retailing, vol. 9781461415, 2012, pp. 1-315.

[21] V.A. Zeithaml, L.L. Berry, and A. Parasuraman, "The behavioral consequences of service quality," J. Mark., vol. 60, no. 2, pp. 31-46, 1996.
[22] S. Mohd-Ramly and N. A. Omar, "Exploring the influence of store attributes on customer experience and customer engagement," Int. J. Retail Distrib. Manag., vol. 45, no. 11, pp. 1138-1158., 2017.

[23] T.W. Andreassen and B. Lindestad, "Customer loyalty and complex services. The impact of corporate image on quality, customer satisfaction and loyalty for customers with varying degrees of service expertise," Int. J. Serv. Ind. Manag., 1998.

[24] R.L. Oliver, Satisfaction: A Behavioral Perspective on the Consumer, Second. Londong and New York: Routledge-Taylor \& Francis Group, 2014

[25] O. Bouzaabia, A. C. r. Van Riel, and J. Semeijn, "Managing in-store logistics: A fresh perspective on retail service," J. Serv. Manag., 2013.

[26] R.J. Brodie, L.D. Hollebeek, B. Jurić, and A. Ilić, "Customer engagement: Conceptual domain, fundamental propositions, and implications for research,” J. Serv. Res., vol. 14, no. 3, pp. 252-271, 2011.

[27] S. Thomas, "Linking customer loyalty to customer satisfaction and store image: a structural model for retail stores," Decision, vol. 40, no. 1-2, pp. 15-25, 2013.

[28] W. Irfan, D.A. Siddiqui, and W. Ahmed, "Creating and retaining customers: perspective from Pakistani small and medium retail stores," Int. J. Retail Distrib. Manag., vol. 47, no. 4, pp. 350-367, 2019.

[29] E.W. Anderson, C. Fornell, and D.R. Lehmann, "Customer satisfaction, market share, and profitability: Findings from Sweden," J. Mark., vol. 58, no. 3, pp. 53-66, 1994.

[30] E. Sivadas and J.L. Baker-Prewitt, "An examination of the relationship between service quality, customer satisfaction, and store loyalty," Int. J. Retail Distrib. Manag., vol. 28, no. 2, pp. 73-82., 2000.

[31] N.Malhotra, N.K., Baalbaki, I.B, and Bechmati, Marketing Research. UK: Peorson-Prantice Hall, 2003.

[32] J. Nunnally, Psychometric Theory(2nd ed). 1978

[33] J. Hair, C. L. Hollingsworth, A. B. Randolph, and A. Y. L. Chong, "An updated and expanded assessment of PLS-SEM in information systems research," Ind. Manag. Data Syst., vol. 117, no. 3, pp. 442-458., 2017.

[34] C. Fornell and D.F. Larcker, "Evaluating structural equation models with unobservable variables and measurement error," J. Mark. Res., vol 18 , no. 1 , pp. 39-50, 1981

[35] I.H. Nunnally, J.C. and Bernstein, Psychometric Theory, 3rd ed. New York: McGraw-Hill/Irwin, 1994

[36] R.P. Bagozzi and Y. Yi, "On the evaluation of structural equation models," J. Acad. Mark. Sci., vol. 16, no. 1, pp. 74-94, 1988.

[37] R.R. Sinkovics, J. Henseler, C.M. Ringle, and M. Sarstedt, "Testing measurement invariance of composites using partial least squares," Int. Mark. Rev., 2016.

[38] C. Fornell, M. D. Johnson, E. W. Anderson, J. Cha, and B. E. Bryant, "The American customer satisfaction index: nature, purpose, and findings," J. Mark., vol. 60, no. 4, pp. 7-18, 1996. 